\title{
MAKING MEN
}

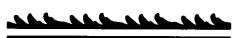





\section{Making Men}

Gender, Literary Authority, and Women's Writing in

Caribbean Narrative

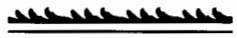

BELINDA EDMONDSON

Duke University Press Durham and London I 999 


\section{(C) 1999 Duke University Press}

All rights reserved

Printed in the United States of America

on acid-free paper $\Theta$

Typeset in Sabon by Keystone Typesetting, Inc.

Library of Congress Cataloging-in-Publication

Data appear on the last printed page of this book.

A portion of chapter 4 originally appeared as

"Black Aesthetics, Feminist Aesthetics, and

Problems of Oppositional Discourse," Cultural

Critique 22 (fall I 992): 75-98. Reprinted by permission of Oxford University Press. 
For my parents,

Dorothea and Locksley,

with love 
